\title{
A databank able to be used for identifying and authenticating commercial flatfish (Pleuronectiformes) products at the spe- cies level using isoelectric focusing of native muscle proteins
}

\author{
Peter Bossier* \& Kris Cooreman \\ Ministerie van Middenstand en Landbouw, Centrum voor Landbouwkundig Onderzoek-Gent, Departement Zeevisserij, Anker- \\ straat 1, 8400 Oostende, Belgium
}

(Received9 August 1999; Accepted in revised form 13 April 2000)

\begin{abstract}
Summary
A computerized databank of IEF protein patterns for use in identifying flatfish species (in total 17 species, including 15 commercial ones) is presented. The databank includes all species regulated by the Belgian Law (22 May 1996) on the use of official names for fishes and seafood products. It was found that interspecimen similarity of the IEF patterns, as processed by digitization, was always larger than interspecies similarity, which allows for unequivocal authentication of unknown samples, as long as the authentic pattern is available in the databank. The databank was used to authenticate 17 commercial fish fillets.
\end{abstract}

Keywords Computer-based identification, IEF, seafood.

\section{Introduction}

Since 22 May 1996 Belgian law has enforced the use of official names for the labelling of fish and seafood products. Flatfish species are economically important species for the Belgian fisheries, representing about $50 \%$ of the annual catch in 1996 and about $80 \%$ of the economic value at auction. Sole (Solea solea) alone represented about $50 \%$ of the total value in 1996. Because of its fine texture and taste and limited supply this species is highly appreciated. The auction value of less-appreciated species such as $\mathrm{Mi}$ crostomus kitt, Pleuronectus platessa and Limanda limanda is 3-6 times less than sole (S. solea).

Involuntary or deliberate mislabelling can be a problem, especially when these or other flatfish species are sold as fresh or frozen fillets. Since fillets of most flatfish species are sold unprocessed (except for, e.g. Hippoglossus spp. or Reinhardtius hippoglossoides, which are often sold smoked) authentication of fish fillets can be carried out by generating species-specific protein patterns. Genetic tools have been described for authentication of processed fish

*Correspondent: Fax: +32 593306 29;

e-mail:pbossier@dma.be products (Bossier, 1999). Identification of fish products by IEF (isoelectric focusing) of water-soluble proteins has been used for some time (Toom, 1982; Sotelo et al., 1993), and the methodology can be standardized in order to obtain reproducible and reliable results (Rehbein et al., 1995). The method has been used to identify red snapper (Lutjanus campechanus; Huang et al., 1995; Hsieh et al., 1997), pufferfish species (Lagocephalus spp.; Kazuta, 1993), eel (Rehbein, 1998) and rockfish species (Sebastes spp,; Lundstrom, 1983). A catalogue of electrophoretic patterns of commercial fish species has been published by Durand et al. (1985), and via the Internet (http://vm.cfscan.fda.gov) the IEF patterns of many species are available from the US Food and Drug Administration.

Identification of species in all these cases relies on the visual comparison of IEF profiles with the references produced on the same gel or on a previous gel. In recent years user-friendly software has become available which allows for the construction of databases that can be used for computer-assisted identification of unknown samples.

Here, we have tested the hypothesis that such a computerized identifying databank of IEF patterns of sarcoplasmic proteins of all flatfish species, de- 
scribed in Belgian law as mentioned above, can be developed. This databank was used to authenticate frozen flatfish fillets sold in 1996 in supermarkets or retail shops.

\section{Material and methods}

\section{Authentic fish species and commercial fillets}

Authentic whole fish species (except for $S$. senegalensis, which were aquacultured specimens obtained from IPIMAR, Portugal) were either caught during voyages of research vessels or commercial vessels, or bought in local retail shops or at fish auctions. The species were identified on the basis of external morphological characteristics according to Poll (1947) and stored frozen at $-20^{\circ} \mathrm{C}$. For some other species authentic material (e.g. whole fish) was not available (seeTable 1). For these species frozen fish fillets were obtained through fish processing companies, hence the authenticity of these samples is not totally unequivocal. Two different Cynoglossus spp. were introduced into the databank. They were not specified here as Belgian law on official names of seafood products demands the use of one Dutch or French name for all Cynoglossus spp. Commercial fillets were bought in supermarket or retail shops during 1996 (in Fig. 1 they are appear labelled as 'opl').

\section{Protein extraction}

About $25 \mathrm{~g}$ fish meat was minced and subsequently mixed with $25 \mathrm{~mL} \mathrm{CCl}_{4}$ in a morter. The $\mathrm{CCl}_{4}$ was decanted after $30 \mathrm{~min}$. The fish meat was transferred to a Waring blender beaker and $15 \mathrm{~mL}$ of glycinebase buffer was added (glycine buffer: $1 \%$ glycine in distilled water, $\mathrm{pH}$ 6.5). After $15 \mathrm{~s}$ mixing at low speed the content was transferred to a centrifuge tube. The supernatant ( $10 \mathrm{~min}$ at $20000 \mathrm{~g}$ ) was filtered (S\&S 595 1/2). Total protein concentration was determined (using the Lowry method) and the filtrate was adjusted to $5 \mathrm{mg}$ protein $\mathrm{mL}^{-1}$ using glycine extraction buffer. Extracts were stored for a short time at $-20^{\circ} \mathrm{C}$.

\section{Electrophoresis}

Using Ampholine PAG plates ( $\mathrm{pH}$ range 3.5-9.5, Pharmacia) in combination with a Multiphor II electrophoresis equipment (Pharmacia), proteins (15 $\mu \mathrm{g}$ spotted on paper strips) were separated ac-

Table 1 Analysed flatfish species.

\begin{tabular}{|c|c|c|c|c|}
\hline Species & $\begin{array}{l}\text { Belgian } \\
\operatorname{law}^{1}\end{array}$ & $\begin{array}{l}\text { Commercial } \\
\text { species }\end{array}$ & $\begin{array}{l}\text { Morphological } \\
\text { authentication }\end{array}$ & Family \\
\hline Glytocephalus cynoglossus & + & + & + & Pleuronectidae \\
\hline Hippoglosoides platessoides & + & + & + & Pleuronectidae \\
\hline Hippoglossus hippoglosus & + & + & - & Pleuronectidae \\
\hline Limanda limanda & + & + & + & Pleuronectidae \\
\hline Microstomus kitt & + & + & + & Pleuronectidae \\
\hline Platichthys flesus & + & + & + & Pleuronectidae \\
\hline Pleuronectus platessa & + & + & + & Pleuronectidae \\
\hline Reinhardtius hippoglossoides & + & + & - & Pleuronectidae \\
\hline Solea lascaris & + & + & + & Soleidae \\
\hline Solea solea & + & + & + & Soleidae \\
\hline Solea senegalensis & - & + & + & Soleidae \\
\hline Monochirus luteus & - & - & + & Soleidae \\
\hline Cynoglossus spp. & + & + & - & Cynoglossidae \\
\hline Lepidorhombus whiffiagonis & + & + & + & Scophthalmidae \\
\hline Psetta maxima & + & + & + & Scophthalmidae \\
\hline Scophthalmus rhombus & + & + & + & Scophthalmidae \\
\hline Arnoglossus laterna & - & - & + & Bothidae \\
\hline
\end{tabular}

${ }^{1}$ Belgian law refers to species specified with Latin, Dutch, French and German names in the Belgian law of 22 May $1996 .{ }^{2}$ Morphological identification: +, whole fish available and identified according to Poll (1947); - , only fish fillets available obtained from fish processing companies. 


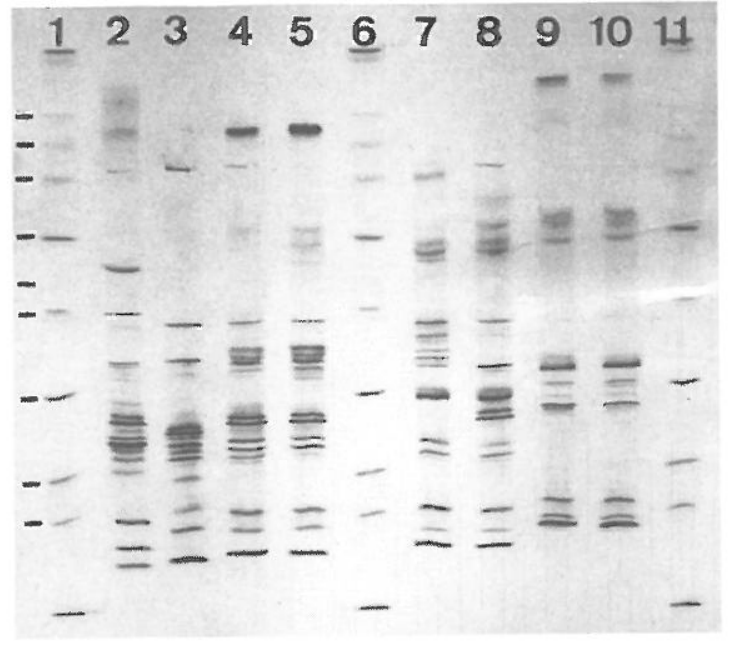

Figure 1 The IEF protein patterns of flatfish species. Each lane represents a digitized IEF pattern. Pearson correlation coefficients were calculated between all patterns resulting into a similarity matrix. On the basis of this similarity matrix an UPGMA dendrogram was calculated. 'opl': commercial fish fillet from an unknown species. The small thick bar at the top of the figure represents an area characterized by the presence of a band (in almost all lanes) originating from the filter paperaided loading of the proteins. This area is omitted from the pattern when Pearson correlation coefficients were calculated. pI values from left to right: $4.55 ; 5.2 ; 5.85 ; 6.55 ; 6.85 ; 7.35 ; 8.15$; $8.45 ; 8.65$.

cording to their $\mathrm{pI}$ (isoelectric point: position in the $\mathrm{pH}$ range where a protein has no net charge and hence zero electrophoretic mobility) at $5{ }^{\circ} \mathrm{C}$ (electrophoretic conditions: $\max 1400 \mathrm{~V}$; $\max 20 \mathrm{~mA}$; $\max 10 \mathrm{~W})$. The distance between the electrodes was $10 \mathrm{~cm}$. Fish protein samples were placed at 2 $\mathrm{cm}$ from the cathode. In order to facilitate standardization of protein patterns, a pI standard (Pharmacia 3.5-9.3 pI range) was also run on the gel. On one gel containing eight samples three standard $\mathrm{pI}$ ladders were loaded. The $\mathrm{pI}$ ladder was loaded at $7 \mathrm{~cm}$ distance from the cathode.

\section{Fixing and staining}

The gels were fixed for $10 \mathrm{~min}$ (trichloroacetic acid $115 \mathrm{~g} \mathrm{~L}^{-1}$, sulphosalicylic acid $34.5 \mathrm{~g} \mathrm{~L}^{-1}$ ), soaked in destaining solution for $30 \mathrm{~min}$ ( $25 \%$ ethanol, $0.8 \%$ acetic acid), stained at $60{ }^{\circ} \mathrm{C}(25 \%$ ethanol, $0.8 \%$ acetic acid, Coomassie brilliant blue R250 1.15 $\mathrm{g} \mathrm{L}^{-1}$ ) for $10 \mathrm{~min}$, destained for $24 \mathrm{~h}$ in a destain bath (Biorad 556) and soaked in preserving solution $\left(10 \%\right.$ glycerol). Gels were dried at $80{ }^{\circ} \mathrm{C}$ under vacuum.

\section{Image analysis}

Gels were digitized with a flat bed scanner (HPscanJet IIcx) at $400 \mathrm{dpi}$. The images were processed and analysed using the software package GelCompar (version 4.1, Applied Maths, Kortrijk, Belgium; http://www.applied-maths.com). The GelCompar software standardized gels in the following way: one $\mathrm{pI}$ ladder was chosen as a database standard and all subsequent gels added to the database were normalized against that $\mathrm{pI}$ ladder. The corresponding protein bands of the ladders were associated with the protein bands in the database $\mathrm{pI}$ ladder. In a next step the $\mathrm{pI}$ ladders on the incoming gel were aligned against the database standard. During the process, bands in sample lanes, lying between two pI ladder lanes, were moved along in a proportional manner. This procedure, in principle, compensated for distortions between lanes on the same gel and for between-gel variations in running conditions. Pearson (product-moment) correlation coefficients (PCC) were calculated between the patterns (Pearson, 1926). This coefficient calculated the congruence between arrays of values, which in this case were densitometric arrays. The PCC compared densitometric curves as a whole, making band definition superfluous. When PCC values between patterns were calculated the software allowed for small shifts of the patterns (optimization) with respect to each other, which could compensate for between-lanes variability in an IEF gel that was not corrected by standardizing gels. This procedure could be performed on one digitized gel or on a computer-aided composed gel, as shown in Fig. 2. In order to validate the procedure, the similarity between the patterns produced and processed by the GelCompar software was investigated. Extracts of four different species (Pleuronectus platessa, S. solea, $M$. kitt and $L$. limanda) were stored frozen $\left(-20^{\circ} \mathrm{C}\right)$ and aliquots were run on five consecutive IEF gels (data not shown). The patterns were standardized against the databank pI ladders and compared with each other. Subsequently, similarities on the basis of Pearson correlation coefficients were calculated with different software settings. We particularly investigated which degree of optimization would gen- 


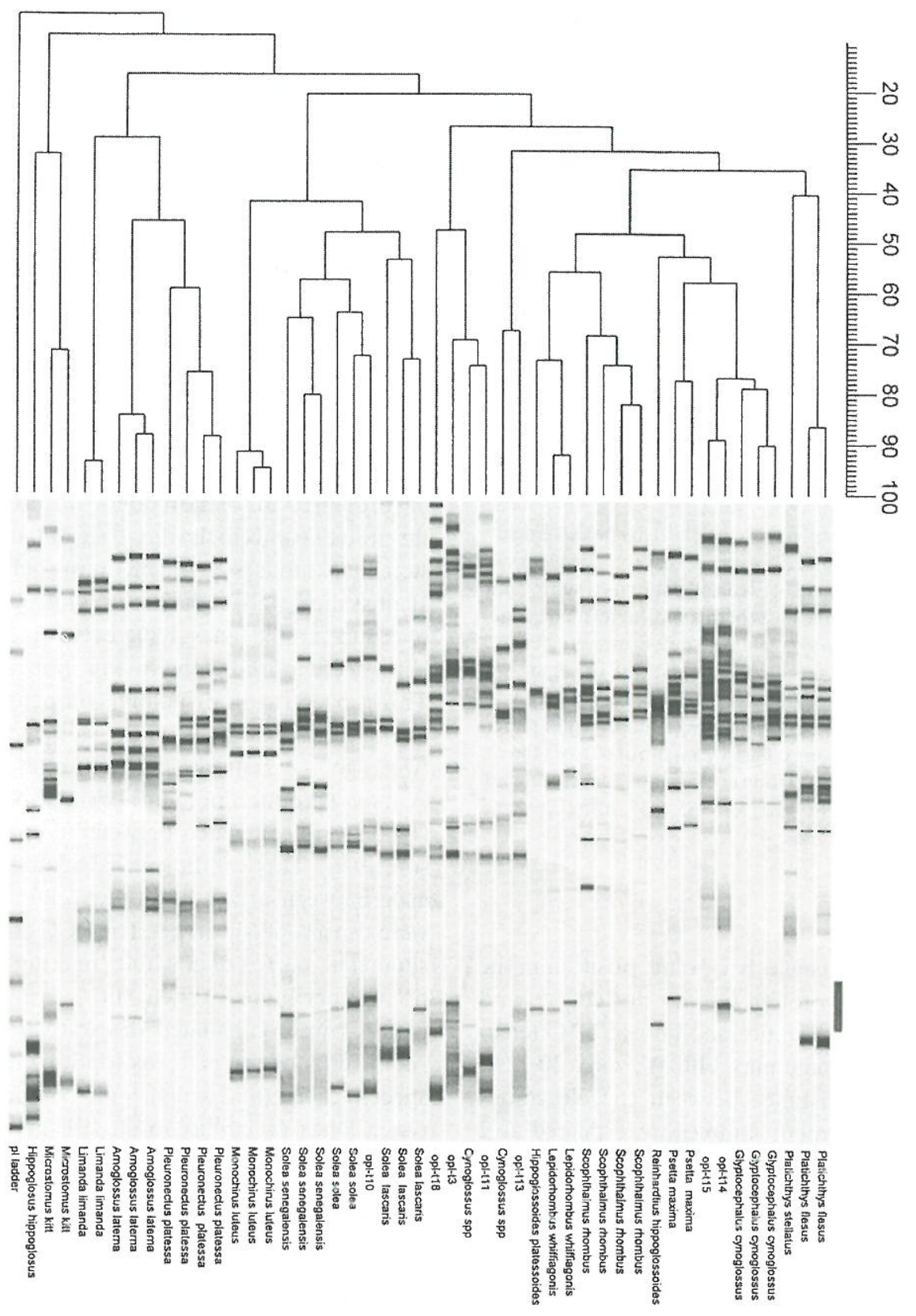

Figure 2 An IEF gel showing the IEF pattern of four different flatfish species and eight different specimens. Lanes 1, 6, 11: pI ladder. The pI markers are from anode (bottom) to cathode (top): 4.55, 5.2, 5.85, 6.55, 6.85, 7.35, 8.15, 8.45, 8.65. Lane 2: Scophthalmus rhombus; lane 3: Psetta maxima; lanes 4 and 5: Platychthys flesus, two specimens; lanes 7 and 8: Pleuronectus platessa, two specimens; lanes 9 and 10: Limanda limanda, two specimens. Notice the polymorphism between the two P. platessa specimens. Polymorphism was highest in P. platessa, see Fig. 1.

erate the highest degree of similarity between the various IEF patterns of the same fish. It was found that under the given experimental conditions, the si- milarity increased gradually when the maximal shift setting was increased from $0 \%$ over $1 \%$ to $2 \%$ (average Pearson correlation, respectively, 65.4, 76.4\% 
and $77.2 \%$ ). The $2 \%$ setting was maintained in the analysis of IEF patterns of species.

A dendrogram was constructed using the PCC values as input to an UPGMA program (unweighted pair-group method of arithmetic averages; Swofford \& Olsen, 1996).

\section{Results and discussion}

\section{Variability due to polymorphic patterns}

A typical result of an IEF gel is presented in Fig. 2. It shows that not all specimens produced an identical IEF pattern, but that polymorphism could be detected. This source of variability was investigated in 10 different species. For these 10 different species two or three specimens were analysed (Fig. 1). The average Pearson correlation coefficient over 10 species was $79.9 \pm 11.5 \%$ (mean \pm standard deviation), which meant that much variability was detected between specimens in the IEF patterns as processed by the GelCompar software. However, in the generated UPGMA dendrogram, $\mathrm{pI}$ patterns from different specimens of the same species were always clustered together, indicating that similarity between the 17 species was lower than between specimens. This finding corroborates Rehbein et al. (1995), who stated that species identification with IEF is possible. The high degree of variability observed between specimens was caused particularly by the polymorphic patterns of the species $P$. platessa and Solea (see Figs 1 and 2). Especially for the Solea spp., similarity between species is sometimes close to the level of similarity between specimens. These observations emphasized the need to include IEF patterns of various specimens in a databank, as this might increase its identifying power.

\section{The IEF databank of identifying patterns}

The dendrogram in Fig. 1 shows the IEF patterns of all species investigated. It demonstrates that species belonging to the family Soleidae tend to cluster together. The non-commercial $M$. luteus, together with the species of the genus Solea, form one cluster. Members of other families (Scophthalmidae, Bothidae and Pleuronectidae, see also Table 1) do not seem to cluster together, but are scattered throughout the dendrogram. This finding indicates that the IEF technique, in combination with the clustering technique used, is not powerful enough to allocate species to families. The results from members of the genus Solea demonstrates that intergenus variability can be large. This observation underlines that the identification of an unknown sample can only be performed in a reliable way if the authentic pattern is available in the database. The two species in the databank with the highest similarity were $S$. solea and $S$. senegalensis (at the $60 \%$ level) and, in general, similarity between specimens (in the entire databank) was not lower than $60 \%$. Hence, although somewhat arbitrarily, the $60 \%$ similarity level could be used as a cut-off point below which the similarity of an unknown sample to an authentic databank pattern could not be interpreted as an unequivocal identification. The dendrogram also shows that the two Cynoglossus references in the database were hardly related. As those samples were obtained through a fish processing company as fillets, the authenticity of these $\mathrm{pI}$ patterns remains equivocal.

Using the databank, the identity of 17 commercial and frozen fillet samples was examined. Nine were labelled as $S$. solea. Four were correctly labelled (e.g. opl-t10), while five were incorrectly labelled. One sample (opl-t15, Fig. 1) produced an IEF pattern that was closely related to Glyptocephalus cynoglossus. Four other patterns, namely opl-t13, t11, t3 and $\mathrm{t} 18$, were also found not to be $S$. solea, but seemed to be related to either of the two Cynoglossus species (non-authenticated references, see Table 1). The relatedness of sample opl-t18 was not high enough to ensure an unequivocal identification. This sample did not contain fish meat from other species available in the databank, as relatedness to them was extremely low. It is possible that this commercial fillet contained fish meat from Cynoglossus species not available in the databank. Three commercial samples were correctly labelled as Cynoglossus spp., while two samples labelled as $M$. kitt contained either G. cynoglossus (opl-t14) or could not be identified. Finally, three samples labelled as L. limanda contained G. cynoglossus fillets (data not shown). In total, seven samples were correctly labelled while eight were incorrectly labelled. Two samples could not be identified unequivocally most probably because the authentic pattern is still lacking in the database. These data illustrated that mislabelling of commercial frozen fish fillets, sampled during the year 1996 in retail shops, was not exceptional.

The software GelCompar allows for the integra- 
tion of whatever gel is chosen into the databank as long as it carries the same pI standard ladder. Therefore, an IEF pattern available via the Internet was compared with the patterns in the databank. The IEF pattern of Platichthys stellatus produced by the US Food and Drug Administration (FDA) (http://vm.cfsan.fda.gov//frf/rfe2fgs.html) was picked from the Internet and introduced into the databank. The pattern linked with that of Platichthys flesus (Fig. 1), although with a very low degree of correlation, as could be expected for two species of the same genus. Integration of IEF patterns produced by more than one laboratory into one databank would require thorough standardization of the methodology, such as protein extraction and determination procedures, and standardization of the settings for the digital processing of gels. Since standardization of the IEF authentication procedure has been proven to be possible (Rehbein et al., 1995), it should be feasible to proceed with the construction of an identifying databank of fish IEF patterns produced in various laboratories.

\section{Conclusion}

Our results confirm that authentication of fish fillets by IEF of water-soluble proteins is feasible and that a computerized databank can assist in the process. Thorough standardization of the IEF procedure would raise the possibility of exchanging authentic IEF patterns between laboratories.

\section{Acknowledgments}

We thank Pieters Visbedrijf for supplying some fish species and IPIMAR (Portugal) for supplying $S$. senegalensis. We also thank J. De Riek and M. De Loose from CLO-DVP for the use of the GelCom- par software and M. Vandenbouhede (CLO-DVZ) for technical assistance.

\section{References}

Bossier, P. (1999). Authentication of seafood products by DNA patterns. Journal of Food Science, 64, 189-193.

Durand, P., Landrien, A. \& Quero, J.L. (1985). Catalogue Électrophorétique Des Poissons Commerciaux. Nantes, France: Institut Français de Recherche pour l'Exploitation de la Mer.

Hsieh, Y.H.P., Chen, F.C. \& Nur, M. (1997). Rapid species identification of cooked red snapper using isoelectric focusing. Journal of Food Science, 62, 15-19.

Huang, T.S., Marshall, M.R. \& Wei, C.I. (1995). Identification of red snapper (Lutjanus campechanus) using electrophoretic techniques. Journal of Food Science, 60, 279-283.

Kazuta, I. (1993). Distinction of pufferfish species by gel electrophoresis. Physico-Chemical Biology, 37, 65-69.

Lundstrom, R.C. (1983). Identification of Pacific rockfish (Sebastes) species by isoelectric focusing. Journal of Association of Official Analytical Chemists, 66, 974-980.

Pearson, K. (1926). On the coefficient of racial likeliness. Biometrika, 18, 105-117.

Poll, M. (1947). Poissons Marins. Brussels, Belgium: Musée Royal d'Histoire naturelle de Belgique.

Rehbein, H. (1998). Differenzierung roher und geräuchter Aale durch protein-und DNA-Analyse. Informationen Fischwirtschaft, 45, 23-25.

Rehbein, H., Etienne, M., Jerome, M., et al. (1995). Influence of variation in methodology on the reliability of the isoelectric focusing method of fish species identification. Food Chemistry, 52, 193-197.

Sotelo, C.G., Pineiro, C., Gallardo, J.M. \& Perez-Martin, R.I (1993). Fish species identification in seafood products. Trends in Food Science and Technology, 4, 395-401.

Swofford, D.L., Olsen, G.J., Waddell, P.J. \& Hillis, D.M. (1996). Phylogenetic interference. In: Molecular Systematics (edited byD.M. Hillis, C. Moritz \& B.K. Mable). Pp. 407-514. Sunderland, USA: Sinauer Associates, Inc.

Toom, P.M., Ward, C.F. \& Weber, J.R. (1982). Identification of fish species by isoelectric focusing. In: Chemistry and Biochemistry of Marine Food Products (edited byR.E. Martin, G.F. Flick, C.E. Hebard \& D.R.Ward). Pp. 51-65.Westport, $\mathrm{CN}$ : AVI Publishing Co. 